\author{
Asian Journal of \\ Medical and Biological Research \\ ISSN 2411-4472 (Print) 2412-5571 (Online) \\ www.ebupress.com/journal/ajmbr
}

\title{
Article \\ Molecular characterisation of oomycetes from fish farm located in Mymensingh sadar during summer
}

\author{
K. M. Mahfujur Rahman and Mohammad Nasif Sarowar* \\ Department of Fisheries Biology and Genetics, Bangladesh Agricultural University, Mymensingh-2202, \\ Bangladesh \\ *Corresponding author: Dr. Mohammad Nasif Sarowar, Department of Fisheries Biology and Genetics, \\ Bangladesh Agricultural University, Mymensingh-2202, Bangladesh. Phone: +88 01712 117963; E- \\ mail: n.sarowar@bau.edu.bd
}

Received: 07 June 2016/Accepted: 21 June 2016/ Published: 30 June 2016

\begin{abstract}
Oomycetes, also known as water molds, can cause serious infection to plants and animals especially at lower temperature although they dwell in freshwater and moist ecosystem throughout the year. The aim of this research was to investigate the diversity of oomycetes inhabiting in small water bodies during summer. Three types of samples i.e. water, fish mucus and apparently infected muscle samples of fish were collected from a large fish farm consisting of over 100 medium to large ponds in Mymensingh during summer (March to June) in 2015. A total number of 385 samples (284 of water, 79 of mucus and 22 of apparently infected muscle samples) were collected in $15 \mathrm{ml}$ sterile falcon tubes with baits in each. Eleven of the isolates were isolated in Potato Dextrose Agar (PDA) plates and were identified using molecular methods that included DNA extraction, PCR amplification and subsequent sequencing of the ITS region of the genomic DNA of the samples. BLAST analysis to GenBank revealed that two of the isolates were 99\% similar to Pythium sp. (HQ643814), three of the isolates were 98-99\% similar to Pythium sp. (KT247392), and each of the remaining four isolates was similar up to $99 \%$ to Pythium sp. (KF836354), 99\% to Pythium sp. (EU544193), 99\% to Pythium rhizo-oryzae (HQ643757) and 100\% to Pythium catenulatum (KP862946). Two of the eleven isolates were not assessed due to sequencing error. Phylogenetic analysis revealed that six of the isolates are of clade B1 and three of the isolates are of clade B2 in the Pythium phylogeny. The results partially suggest that plant pathogenic oomycetes are more common in summer than animal or fish pathogenic isolates in the sampled farm however; intensive sampling with a broad range of freshwater ecosystems during summer can give a clearer view on oomycete diversity in Bangladesh.
\end{abstract}

Keywords: Pythium; PCR; sequencing; summer; plant pathogenic

\section{Introduction}

Mycotic diseases of fish are mainly caused by fungal-like organisms called oomycetes often referred to as water molds (van West, 2006). They are capable of infecting different hosts ranging from algae, protists, plants, fungi and arthropods to vertebrate animals (Phillips et al., 2008; Beakes et al., 2012; Sarowar et al., 2013). As a group oomycetes are well known for being pathogenic to plants causing serious economic losses to crops worldwide and also environmental damage in natural and captive ecosystem (van West, 2006). Among the plant pathogenic oomycetes, Phytophthora is the best studied genus (Phillips et al., 2008); species in this genus cause devastating diseases on several crops, ornamental and wild plants (Kamoun, 2009). Phytophthora infestans causes late blight disease in potato and caused great Irish potato famine in mid-1 ${ }^{\text {th }}$ century (Fry et al., 2009). Soybean production is hampered greatly by Phytophthora sojae (Kaufmann and Gerdemann, 1958). Plasmopara viticola that infect wild grape plants was an important plant pathogen in Europe and North America in the late $19^{\text {th }}$ century (Fry and Grünwald, 2010). Phytophthora cinnamomi is a threat to agricultural plants and around 
3000 plants can be affected by this pathogen (Hardham, 2005). Phytophthora ramorum is best known for causing sudden oak death on different oak species (Grünwald et al., 2008). Sclerophthora rayssiae var. zeae and Peronosclerospora philippinensis, the cause of downy mildew of maize in India and Philippines and agents of 20-90\% crop loss annually (Fry and Grünwald 2010). Pythium aphanidermatum and P. ultimum are causal agents of seed rot, seedling damping-off, and root rotof several plants (Fry and Grünwald 2010). Moreover, Pythium insidiosum is the only member of oomycetes that infects mammals and birds (Dick 2001). Animal pathogenic oomycetes are of recent concern in wild as well as in fish culture farms. The most devastating mycotic diseases in fish are saprolegniosis caused by Saprolegnia spp., and epizootic ulcerative syndrome (EUS) caused by Aphanomyces invadans which result severe mortalities in fish of both wild and captive environment (van West 2006).

In Bangladesh most study on mycotic diseases in aquaculture is based on morphological studies. However, most fungi and fungus-like organisms associated fish diseases are unidentifiable to species level using morphological methods, because they have very similar characteristics and often fail to produce sexual organs in vitro (Diéguez-Uribeondo et al., 1996; 2007), or, if they do, it may happen only after a long development time (Xiao et al., 2009). Identification of asexual pathogenic isolates using classical taxonomic criteria is impractical and also difficult (Fernandez-Beneitez et al., 2007; Diéguez-Uribeondo et al., 1996). Furthermore, species identification has been more challenging because it has required presence of the sexual structures (Petrisko et al., 2008). However, recent developments in molecular biology have made it possible to identify fish pathogenic oomycetes at species level which is more reliable, time saving and non-questionable (Robideau et al., 2011).

Oomycetes are phylogenetically very distant from the Kingdom Eumycota, the true Fungi, unlike their initial appearance would suggest. There are several developmental stages in the life cycle of oomycetes distinct from the true fungi (Beakes et al. 2012). Fishes are more susceptible to mycotic diseases such as saprolegniosis or EUS in winter with low and/or dropping water temperatures, related to impaired immune function at lower temperatures (Noga, 1993). For example, A. invadans, is very effective at $18-22{ }^{\circ} \mathrm{C}$ water temperature or less in infecting fish (Bondad-Reantaso et al., 1992). In low water temperatures oomycetes undergo asexual reproduction. During critical environmental conditions such as dryness or extreme temperature, the oomycetes undergo sexual reproduction for survival. It is one of the major evolutionary developments that define more advanced oomycetes (Beakes et al., 2012). The sexual phase is thought to enable survival until conditions become more favorable for germination (Sarowar et al. 2014). Strategies of survival employed by oomycetes in harsh conditions have been reported (Sarowar et al. 2014, Judelson 2009), however, there is no clear description about survival strategy of oomycetes in summer when infection in fish is less frequent.

Recent developments in molecular biology have made it possible to identify fish pathogenic oomycetes at species level which is more reliable, time saving and non-questionable (Robideau et al., 2011). The internal transcribed spacer (ITS) region of the rRNA gene of oomycetes is mostly used for DNA sequencing (Peay et al. 2008). By comparing ITS nucleotide sequences, it is possible to develop accurate phylogenetic relationships (Lee and Taylor 1992). Furthermore, as non-coding regions, ITS evolves more rapidly than coding regions such as large subunit rRNA (28S rRNA), small subunit rRNA (18S rRNA) and 5.8S rRNA, and can be useful for comparisons at the species or population level (Matsumoto et al., 1999). ITS region sequencing, therefore, is an excellent approach compared to morphological methods that can be used to identify and define oomycete species.

There are hardly any studies on the diversity of these pathogenic oomycetes during summer season which would reflect surviving strategies employed by the organism. The target of this current research is to identify diversity of oomycetes species in small water bodies during summer and subsequently construct a phylogenetic tree based on Internal Transcribed Spacer (ITS) region of rRNA gene for better understanding of the nature of the collected species compared to already reported species worldwide.

\section{Materials and Methods}

\subsection{Sampling sites and sample collection}

Samples were collected for 8 consecutive weeks from tilapia (Oreochromis niloticus), shing (Heteropnesteus fossilis) and koi (Anabustes tudineus) pond of a well-managed fish farm known as Reliance Aqua Farm of Mymensingh Sadar, Bangladesh in March to June 2015. Three types of samples were collected to investigate the diversity of oomycetes present in the selected ponds during the study period. Water samples from each sampling ponds, mucus samples of brood tilapia, and muscle samples from apparently infected koi and shing were collected in $15 \mathrm{ml}$ sterile falcon tube separately. Water samples $(10 \mathrm{ml})$ were collected from different ponds during each sampling in individual $15 \mathrm{ml}$ falcon tubes containing an autoclaved rice grain that served as bait. Fish mucus samples were $(2 \mathrm{ml})$ collected in the falcon tubes with autoclaved rice grain and was filled with 
autoclaved distilled water $(8 \mathrm{ml})$. In case of apparently infected fish, a small cube of around $0.5 \mathrm{~cm}^{2}$ from infected muscle were cut with a sterile scalpel, and washed with distilled water and soaked up in dry paper to reduce bacterial load before being stored in tube with $10 \mathrm{ml}$ distilled water without placing the rice grain. During collection, all samples were stored in an ice box on the sampling site and immediately brought to laboratory and were kept in refrigerator at $5-6{ }^{\circ} \mathrm{C}$ for two days.

\subsection{Laboratory culture}

Inoculation of water samples and mucus samples were carried out by placing the bait into $9 \mathrm{~cm}$ diameter petri dish in $25 \mathrm{ml}$ potato dextrose agar (PDA; $39 \mathrm{~g}$ in 1 liter $\mathrm{dH}_{2} \mathrm{O}$ and autoclaved) medium supplemented with Vancomycin $(200 \mathrm{mg} / \mathrm{l})$, Ampicilin $(500 \mathrm{mg} / \mathrm{l})$ and Pimaricin $(50 \mathrm{mg} / \mathrm{l})$ while infected muscles (washed with $\mathrm{dH}_{2} \mathrm{O}$ ) placed directly in petri dish with PDA and antibiotics and were sealed with parafilm. Culture plates were maintained at room temperature and check daily for hyphal growth. Once the mycelium has grown into agar, a small agar plug was cut and re-inoculated to a new plate of PDA with antibiotics aseptically several times until no bacterial growth was observed in the oomycetes culture. Cultures were observed for contamination by placing an agar plug of mycelium in petri dish containing $20 \mathrm{ml}$ pea broth $\left(20 \mathrm{ml}\right.$ garden pea in $500 \mathrm{ml} \mathrm{dH}_{2} \mathrm{O}$ and double autoclaved) without antibiotics. The plates were sealed with parafilm and incubated at $20^{\circ} \mathrm{C}$ for three days.

\subsection{DNA extraction}

Once a bacteria free culture was attained, genomic DNA from the mycelia was extracted using a Wizard® Genomic DNA Purification Kit following manufacturer's instructions with some minor modifications to the protocol. The mycelium from the pea broth was completely dried into filter paper (autoclaved). The dried mycelium was homogenized in $500 \mu \mathrm{l}$ nuclei lysis solution supplied with the kit in a sterile tissue homogenizer and transferred into a $1.5 \mathrm{ml}$ flip cap tube aseptically. Three (3) $\mu 1$ RNaseA solution supplied in the kit was added in the tube and inverted several times. The mixture was incubated at $65^{\circ} \mathrm{C}$ for 45 minutes in hot water bath, with inversions every 15 minutes. After being cooled down to room temperature, $200 \mu 1$ of mixture sample was transferred to a new $1.5 \mathrm{ml}$ sterile eppendrof tube and $400 \mu 1$ of protein precipitation solution supplied with the kit was added. The mixture was vortexed vigorously for 5 minutes to emulsify the 2 phases. The tube was centrifuged (Centrifuge $5415 \mathrm{R}$ ) at $16,000 \times \mathrm{g}$ for 5 minutes. The $500 \mu 1$ supernatant containing the DNA was carefully pipetted to a new $1.5 \mathrm{ml}$ sterile eppendrof tube that already contained $500 \mu 1$ isopropanol. The tube was inverted until thread like strand of DNA appeared and incubated at $65^{\circ} \mathrm{C}$ for 5 minutes, before being centrifuged at $4^{\circ} \mathrm{C}, 16,000 \times \mathrm{g}$ for 10 minutes. The supernatant was decanted carefully and the pellet was washed with $300 \mu 170 \%$ ethanol several times. The pellet along with $70 \%$ ethanol was centrifuged at $13,000 \times \mathrm{g}$ for 2 minutes. The ethanol was carefully air-dried and the pellet was re-suspended in $30 \mu 1$ of DNA rehydration solution supplied in the kit. The tube was finally incubated at $65^{\circ} \mathrm{C}$ for 20 minutes, with gently tapping every 10 minutes. In order to determine the DNA concentration, samples were analyzed using an Eppendorf Bio Photometer plus. Each extracted sample was diluted as necessary to obtain a DNA concentration and checked further for quality by electrophoresis on $1 \%$ agarose gel.

\subsection{PCR amplification and band visualization}

PCR reaction was carried outin a thermal cycler (Eppendorf Mastercycler Gradient) to amplify the ITS region of the genomic DNA. To perform the PCR, $5 \mu 12$ x GoTaq $^{\circledR}$ G2 Colorless Master Mix (Promega ${ }^{\circledR}$; contains DNA Polymerase, dNTPs, $\mathrm{MgCl}_{2}$ and reaction buffer) was added with $1 \mu \mathrm{l}$ template DNA ( $\left.\sim 50 \mathrm{ng} / \mu \mathrm{l}\right), 0.3 \mu \mathrm{l}(10 \mu \mathrm{M})$ forward primer (ITS 5 alt: 5 ' TGA AAA GTC GTA ACA AGG TT 3'), $0.3 \mu 1(10 \mu \mathrm{M})$ reverse primer (ITS 4 alt: 5' TCC TCC GCT TAT TGA TAT G 3'), and $3.4 \mu 1$ nuclease free water to make the final reaction volume of $10 \mu \mathrm{l}$. The $0.2 \mathrm{ml}$ sterile PCR tubes were placed in a Mastercycler Gradient, and the PCR reaction was run under the following conditions: 1 cycle at $95^{\circ} \mathrm{C}$ for 5 minutes followed by 30 cycles each having $95^{\circ} \mathrm{C}$ for $30 \mathrm{~s}$, $57^{\circ} \mathrm{C}$ for $30 \mathrm{~s}$ and $73^{\circ} \mathrm{C}$ for 1 minute finishing with a final elongation cycle at $73^{\circ} \mathrm{C}$ for 7 minutes. The reaction mixture was cooled down at $4^{\circ} \mathrm{C}$ for 5 minutes to end the reaction cycle. $1 \%$ Agarose gel $(0.2 \mathrm{~g}$ agarose $/ 20 \mathrm{ml}$ TAE buffer) containing $3 \mu$ l Ethidium Bromide (Promega ${ }^{\circledR}$; conc. $100 \mu \mathrm{g} / \mathrm{ml}$ ) was prepared to test the quality of the DNA. $6 \mu \mathrm{l}$ of a mixture of PCR sample $(5 \mu \mathrm{l}$ PCR product and $1 \mu 16 \times$ loading dye added together) was loaded into each well of the gel with a micropipette. A $1 \mathrm{kbp}$ DNA marker (Promega, USA) was loaded into $1^{\text {st }}$ well in the gel to study the band size. The agarose gel was flooded with $600 \mathrm{ml}$ TAE buffer in a gel running chamber and was run for 70 minutes at $120 \mathrm{~V}$ before photographing under UV light (High Performance Ultraviolet Transilluminator) to visualize DNA bands. 
2.5. DNA sequencing and phylogenetic analysis

PCR amplicons were sent off for Sanger sequencing to 1st BASE, Malaysia. The PCR products were prepared according to the sequencing company's instruction following sample preparation guide. The generated sequences (fasta file) were aligned using Bio Edit software (Version 7.2.5) and consensual sequences introduced in Basic Local Alignment Search Tool (BLAST: http://blast.ncbi.nlm.nih.gov/Blast.cgi) in order to find closest related species. The sequences obtained were compared with homologous sequences in the GenBank (http://www.ncbi.nlm.nih.gov/genbank/) and phylogenetic and molecular evolutionary analyses were conducted using the MEGA version 6 (Tamura et al., 2013). All sequences were aligned by ClustalW and a maximum likelihood phylogeny tree was constructed with 1000 bootstrap replications. Phytophthora polymorphica (GenBank accession no: DQ335636) was used as an out group.

\section{Results}

\subsection{Isolation of oomycetes}

A total of 11 samples showed oomycete like mycelial growth on PDA plates out of collected 385 samples (284 water samples, 79 mucus samples and 22 apparently infected muscles). Isolated 11 mycelia samples were fished out from 284 water samples. No growths of mycelium were observed in mucus and fish samples. Mycelia that were re-inoculated in a new plate showed growth within 12 hours in room temperature.

\subsection{Molecular analysis}

Extracted DNA samples of all isolates were run in a PCR reaction after quantification. The PCR productions were run in $1 \%$ agarose gel electrophoresis and approximately $850 \mathrm{bp}$ band sizes were observed after UV visualization (Figure 1). The nucleotide sequence of ITS of 11 isolates indicated that nine (isolates no. 2, 3, 5, 6, $7,8,9,10$, and 11) of the isolates were Pythium (Table 1) while the chromatogram of 1 and 4 appeared very noisy with background peaks (Figure 2 A, B) which deterred identification of the isolates compared to the rest that had very little or no background peaks (Figure 2 C). For isolates 3 and 4, the bands appeared faint, a secondary PCR was run to get a desired concentration of target amplicon for sequencing. The sequences obtained were compared with homologous sequences in GenBank (table 1). An average of 860 bp of the rRNA ITS region of all the isolates, that is very similar number used in the phylogeny tree construction process, showed that nine (9) of the isolates were identified as the genus Pythuim.

ITS sequences of isolated Pythium species were compared with reference species adapted from Levesque and Cock (2004) and phylogenetic analysis (Figure 3) confirmed that the sequencing results of isolates 2, 3, 5, 8, 9 and 10 are closely related to Pythium catenutalum, Pythium rhizo-oryzae, Pythium torulosum and Pythium folliculosum and isolates 6, 7, and 11 could be Pythium pachycaule and/or Pythium dissotocum based on ITS sequences. ClastulW alignment of 2, 3, 5, 8, and 9 (Figure 4) in BioEdit software revealed that these five isolates are almost identical to each other based on ITS sequence except in four neucleotide pairs placed with some interval which also supports the phylogenetic tree.

Table 1. Isolated species that are closely related to the species enlisted in GenBank and their source of origin.

\begin{tabular}{|c|c|c|c|c|c|}
\hline Isolates No & $\begin{array}{l}\text { Closely related } \\
\text { species } \\
\text { (From GenBank) }\end{array}$ & $\begin{array}{l}\text { Source of species } \\
\text { in the study (fish } \\
\text { pond) }\end{array}$ & $\begin{array}{l}\text { GenBank } \\
\text { accession No. } \\
\text { of the closely } \\
\text { related species }\end{array}$ & $\begin{array}{l}\text { Isolation sources (Country } \\
\text { of origin) }\end{array}$ & $\begin{array}{l}\text { Similarity to } \\
\text { GenBank } \\
\text { accession } \\
\text { No. }\end{array}$ \\
\hline 1,4 & Sequencing error & H. fossilis & $x_{1}$ & - & - \\
\hline 2 & Pythium catenulatum & O. niloticus & KP862946 & $\begin{array}{l}\text { Certified organic soil } \\
\text { (Colambia basin, WA, USA) }\end{array}$ & $100 \%$ \\
\hline 3,5 & Pythium sp. & $\begin{array}{l}\text { A. testudineus, } H . \\
\text { fossilis }\end{array}$ & HQ643814 & $\begin{array}{l}\text { Unknown (Tamberma Land } \\
\text { Togo) }\end{array}$ & $99 \%$ \\
\hline $6,7,11$ & Pythium sp. & H. fossilis & KT247392 & $\begin{array}{l}\text { Greenhouse recycled water } \\
\text { irrigation tank (Pennsylvania, } \\
\text { USA) }\end{array}$ & $98-99 \%$ \\
\hline 8 & Pythium rhizo-oryzae & H. fossilis & HQ643757 & $\begin{array}{l}\text { Soil of paddy } \\
\text { (Gorakhpur, India) }\end{array}$ & $99 \%$ \\
\hline 9 & Pythiu & dineus & KF836354 & Unknown (France) & $99 \%$ \\
\hline 10 & Pythium sp. & A. testudineus & EU544193 & Sediment (USA) & $99 \%$ \\
\hline
\end{tabular}




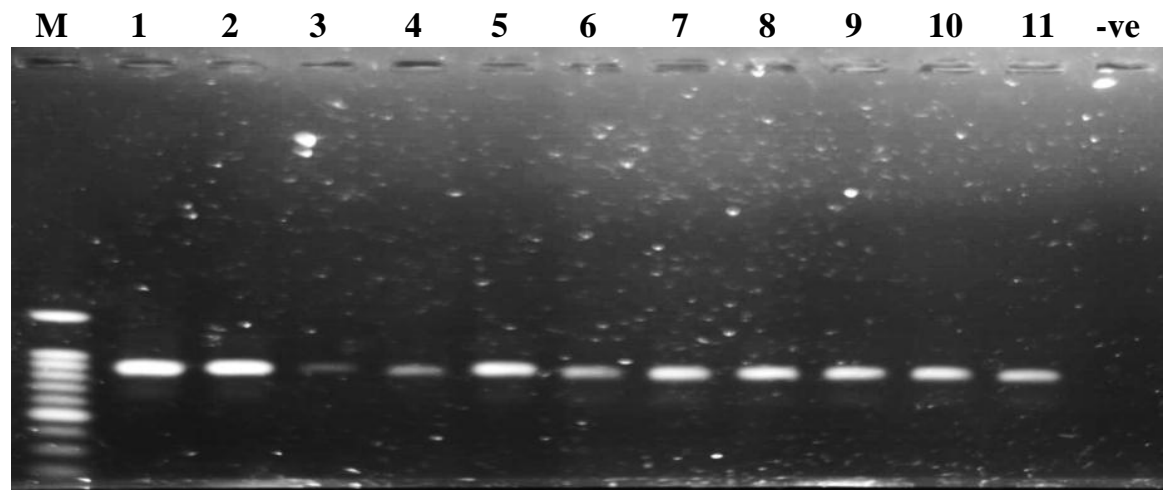

Figure 1.Agarose gel (1\%) run of the PCR products of isolates (1 to 11) produce an approximate band size of 800 - $900 \mathrm{bp}$ that is visualize under $\mathrm{UV} ; \mathrm{M}=1 \mathrm{kbp}$ molecular marker, -ve = negative control (DNAse/RNAse free water).
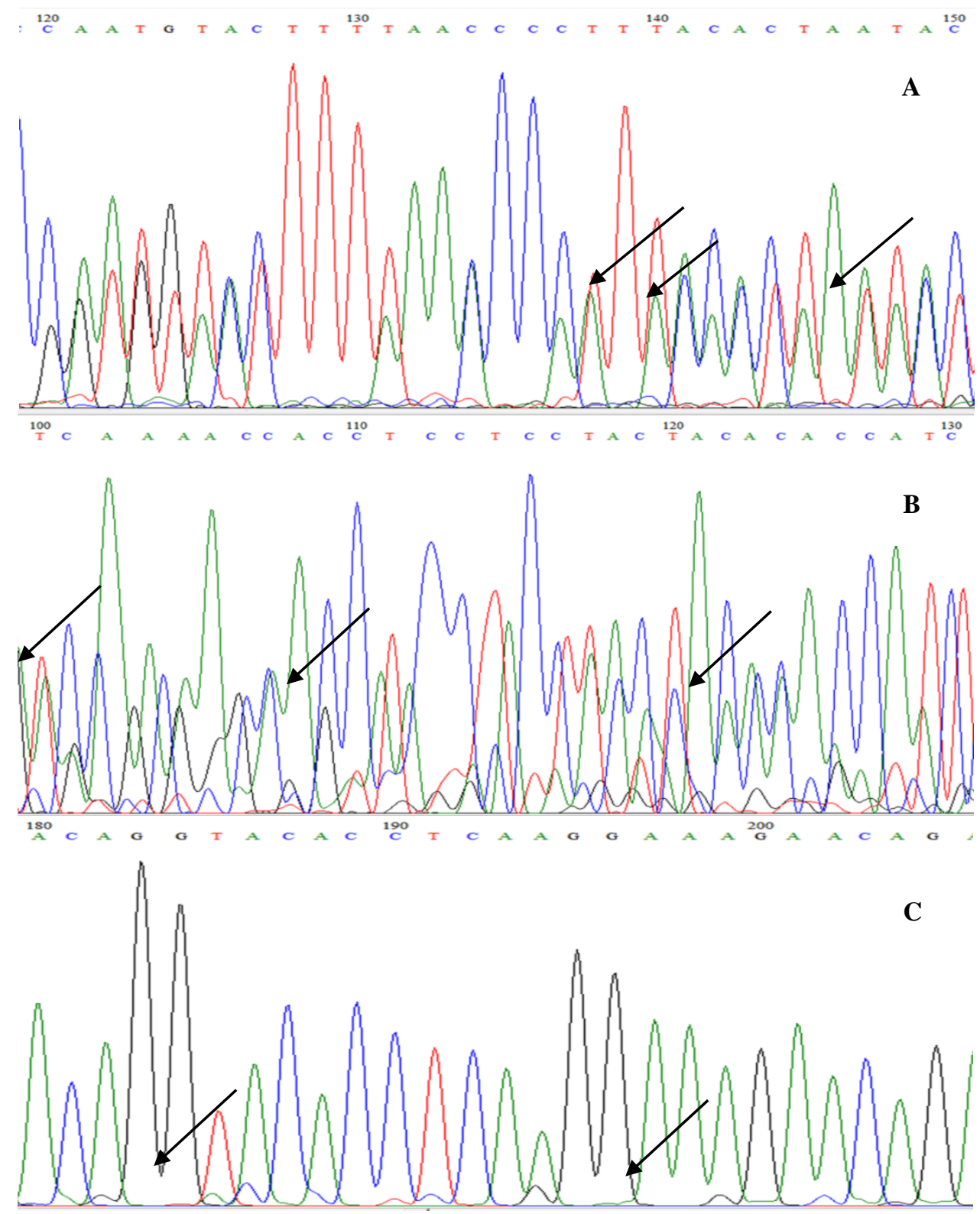

Figure 2. Partial chromatogram of ITS sequencing as seen in the software. Isolate 1 (A) and isolate 4 (B) with noisy backgrounds and isolate 10 (C) with better sequencing data. Arrows indicate some of the background noises. 


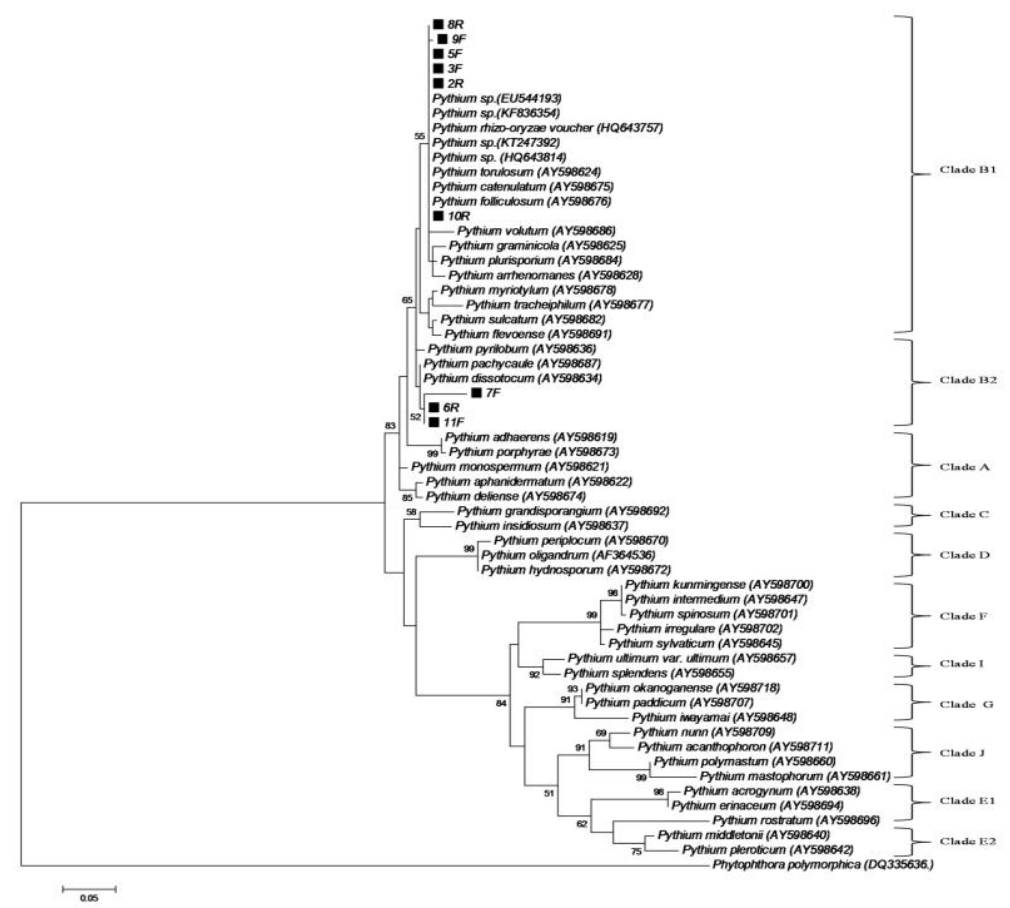

Figure 3. Maximum likelihood phylogram based on ITS showing phylogenetic relationships of the oomycetes isolated $(2 \mathrm{R}, 3 \mathrm{~F}, 5 \mathrm{~F}, 6 \mathrm{R}, 7 \mathrm{~F}, 8 \mathrm{R}, 9 \mathrm{~F}, 10 \mathrm{R}$, and 11F) from the fish ponds that are compared with the homologous sequences adapted from Levesque and Cook (2004) sequence of are retrieved from GenBank. Accession numbers of the sequences are given in bracket. Numbers within the tree represent bootstrap value (1000 replications); values less than $50 \%$ were not noted. Clades in the phylogram represent the species of same groups that was obtained by alignment of the ITS sequences from Genbank and from the current study. Phytophthora polymorphica was used as out-group.

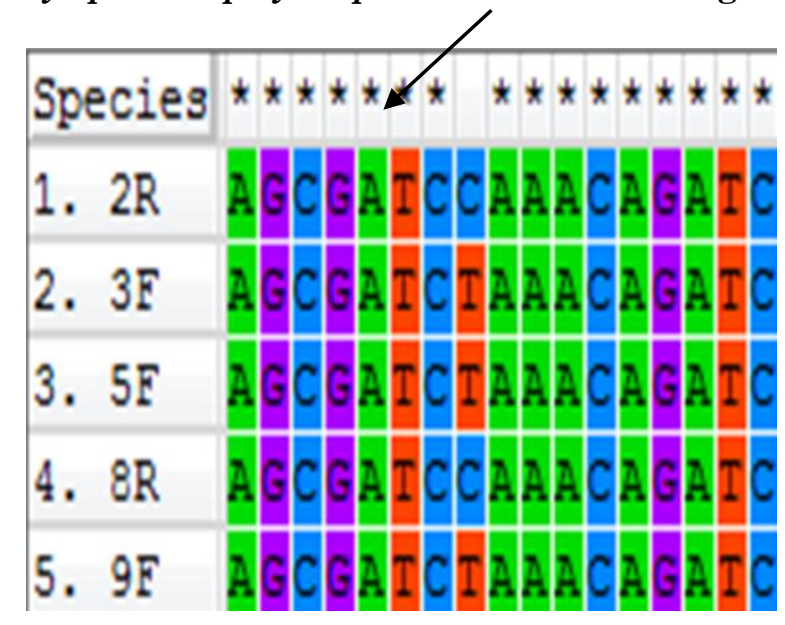

Figure 4. Alignment of 5 isolates $(2,3,5,8$, and 9) by Clastul $W$ showed that isolates were almost identical except differences in four nucleotide base of which one is showed with an arrow. The identical nucleotides are marked by stars at top of the figure. $2 \mathrm{R}, 3 \mathrm{~F}, 5 \mathrm{~F}, 8 \mathrm{R}$, and $9 \mathrm{~F}$ are the alias no of the isolates $2,3,5,8$, and 9 , respectively.

\section{Discussion}

This is the first effort on the molecular identification of oomycetes occurring in small water bodies in Bangladesh. The identified nine oomycetes isolates of Pythium genera (7 isolates of Pythium sp., 1 isolate of Pythium catenulatum, 1 isolate of Pythium rhizo-oryzae) were isolated from the collected water samples of the fish farm. In general, Pythium spp. are known as either plant pathogens or saprotrophs (Alcala, 2013; Robideau et al., 2011). Typical fish pathogenic oomycete such as Saprolegnia spp. were not found in the current study conducted. Pythium spp. have been reported from bony fishes; however, it is yet to be established whether they are primary pathogens of fish (Czeczuga et al., 2002a). In 2000, Czeczuga et al. (2002a) isolated eleven species of Pythium from the muscles of monkey goby (Neogobius fluviatilis), Chinese sleeper (Perccottus glenii), and 
stone morocco (Pseudorasbora parva) inhabiting in the ponds, rivers and spring waters in Poland e.g. Pythium afertile, $P$. aquatile, $P$. arrhenomanes, $P$. butleri, $P$. dissotocum, $P$. hemmianum, $P$. intermedium, $P$. myriotylum, P. ostracodes, $P$. periplocum, and $P$. tenue. These Pythium species have been reported from both dead and live fishes. Sati and Khulbe (1983) reported growth of Pythium diclinumas a parasite on the gills of a few fish species in India; however, $P$. diclinum failed to infect fish in experimental condition. Moreover, Czeczuga (1996) isolated a number of Pythium spp. that grew on the eggs of freshwater fishes sporadically. He assumed that species of Pythium, apart from Saprolegnia and Achlya, contributes significantly to mycosis which may lead to the mass development of pathogenic oomycetes and cause damage to a large number of incubated eggs. Moreover, other than fish, Pythium species were also reported from a number of crustaceans (Czeczuga $e t$ al., 2002b). Czeczuga et al. (2002b) reported forty-three species of Pythium of which most common were Pythium acanthicum, Pythium butleri and Pythium myriotylum in appearance and abundance. Majority of the works that reported Pythium spp. from fish (Czeczuga, 1996; Czeczuga et al., 2002a; 2002b; 2004; Czeczuga and Muszyfska, 1996) were conducted in the water bodies surrounded by forests. It could be that the reported Pythium spp. took the water route to spread throughout the forests and were found on fish. Similar scenario was evident in our sampling site where it was surrounded by paddy and vegetable fields. It might be that the resulted Pythiumspp. in our samplings have originated from the surrounding crop fields and were flushed out to the culture ponds with rains.

The isolated species that gave 100\% similarity with GenBank accession no. KP862946 was P. catenulatum that was isolated from the water samples of the tilapia brood pond. $P$. catenulatum was first cited by Matthews (1931) from turf grasses; however, Balaet al. (2006) stated that the identified species of Matthews were $P$. rizho-oryzae based on ITS sequencing of their collected isolates. He concluded that the presence of numerous catenulate hyphal bodies led the misconception to develop. In 1976, Plaats-Niterink (1981) isolated $P$. catenulatum from plant debris in water, and also from soil and turf grasses in the USA. The first record of $P$. catenulatum in Morocco was cited by Androusse et al. (2007) from the water samples that were collected from different places of dam reservoir. Roudsary et al. (2010) isolated $P$. catenulatum from diseased grass and soil samples from green spaces and sport fields in between 2005-2006 and published as a scientific short note that was the first record of the identified species in Iran. The second species of our study, P. rhizo-oryzae, was collected from the brood shing fish pond of the fish farm. P. rhizo-oryzae was identified as novel species in 2001 from the northeastern India (Bala et al., 2006). They collected some soil samples from paddy fields and studied on the morphological and molecular identification of the isolates. They finally mentioned that $P$. rhizooryzae is closely related to the members producing a filamentous inflated type of sporangia like $P$. catenulatum, $P$. torulosum, and P. inflatum based on ITS sequence.

Phylogeny tree analysis revealed that six of the isolates $(2,3,5,8,9$ and 10) were species of clade B1 (Levesque and Cock, 2004) based on ITS sequence. They stated that species of the clade B1 consist of filamentous-inflated sporangia. Their distribution is worldwide and has mostly been isolated from monocotyledons, bryophytes, green algae and soil, occasionally from dicotyledons and conifers (Levesque and Cock, 2004). According to the databases of GenBank, reported closest match of the isolate 2 was found from certified organic sediment as well as isolate 10 was from sediment and both isolates was collected form USA. Isolate 8 found in our study was reported from soil of paddy field in India (Bala et al., 2006). However, isolate 3 and 5, in the current research, both were Pythium sp. that were sequestered from unknown origin in Togo and isolate 9 were also found from unknown source in France. The tree suggests that all the isolates of clade B1 are Pythium rhizo-oryzae, except isolate 10 in this work which could be Pythium folliculosum or Pythium catenulatum based on ITS sequence. It could also be Pythium rhizo-oryzae since these three species are closely related. Full length ITS as well as CoXII sequences might give a clearer resolution up to species level in this sub-clade of Pythium phylogeny. The search sequence lengths e.g. between 675-810bp added with quality of the sequences can make the difference in the position of a taxa in the phylogenic tree. The results based on phylogenic tree and existing data indicate that the identified isolates of clade B1 collected in this study might had transferred to the fish pond water from the soil of paddy field around the farm.

The other three of the isolates (6,7 and 11) belonged to the species of clade B2 of Pythium genus based on ITS phylogeny (Levesque and Cock, 2004). This group consists of species with filamentous non-inflated to slightly inflated sporangia, smooth oogonia, and a moderate growth rate. Except for P. dissotocum, which is commonly found in several greenhouse crops such as lettuce and tomato, most species seem to be uncommon (Levesque and Cock, 2004). Information on GenBank database suggests that the closest match of the isolates 6, 7 and 11 were separated from greenhouse recycled water irrigation tank in USA. From the tree, the results indicate that the isolates could be Pythium dissoticum. The vegetable plants in the farm are the possible source of $P$. 
dissoticum in the water samples collected from fish ponds of the farm. The result might be also hampered as the search sequence length of the isolates 6,7 , and 11 were only $705 \mathrm{bp}, 660 \mathrm{bp}$ and $710 \mathrm{bp}$ respectively.

A total of 79 mucus samples of fish were collected to observe the diversity of oomycetes occurring in fish farm in summer. Mucus samples of brood tilapia were collected during the study period while mucus of koi and shing were not collected because handling could infect the fishes and could result in economic losses of the fish farm. There were no oomycetes found in the fish mucus samples collected from the brood tilapia. Lilley et al. (1998) stated that tilapia (Oreochromis niloticus), common carp (Cyprinus carpio) and milk fish (Chanos chanos) is somehow naturally resistant to A. invadans. Afzaliet al. (2015) also suggested that tilapia is EUS resistant. They found no mortality in tilapia against EUS. In their work, live zoospores of EUS were injected to show the histopathological responses of tilapia, however, no visible inflammatory response was found. Afzali et al. (2015) stated that in Nile tilapia, fully mature granulomata of varying sizes fused with multinucleated giant cells and formed large granuloma, surrounded with dense fibrous layers and melanin pigments that filled the whole affected area in very early stages of infection. Thompson et al. (1999) suggested that giant cell formation did not seem to be an indicator of resistance to EUS while the actual impact of this type of response in respect to fungal infection is still unclear. According to Afzali et al. (2015), mycotic granulomatous reaction could prevent and halt $A$. invadans growth only in resistant fish such as Nile tilapia, however in susceptible fish, for example snakehead, gouramies, koi carp, catfish, goldfish, and climbing perch, the rate of hyphal growth was more rapid than granulomatous reaction. Granulomatous reaction could not be an indicator of susceptibility or resistance to the EUS as it varied to the cellular responses of different fish species. Another research of Khan et al. (1998) stated that out of 16, only 2 tilapias died at 20 and 21 days post inoculation of A. invadans. The histology of the dead tilapia revealed hyphae inside the granulomas and were surrounded by epithelioid cells. Dramatic granulomatic response with fibrous tissue layer formation and a few lymphocyte aggregations along with foreign body type giant cells were also apparent. They concluded as the injection of spores inside the muscles of tilapia circumvented the means of protection. Thus, it is difficult to trap oomycetes in the mucus samples of EUS resistance Nile tilapia.

Apparently infected muscle samples of koi (10 samples) and shing (12 samples) were collected during the research. The infected koi and shing samples were collected in $24^{\text {th }}$ April and $12^{\text {th }}$ May respectively in 2015 that represent summer season in Bangladesh. However, fish or plant pathogenic oomycetes were not found in apparently infected muscle samples collected from fish farms in the summer season indicated that the infection in koi and shing may be of bacterial origin.

All of the 11 identified Pythium species were found in water samples during $3^{\text {rd }}$ sampling $\left(11^{\text {th }}\right.$ April, 2015) and $8^{\text {th }}$ sampling ( $8^{\text {th }}$ June, 2015). There was heavy rainfall before the $3^{\text {rd }}$ and $8^{\text {th }}$ sampling days resulting in lower water temperature $\left(15^{\circ} \mathrm{C}\right)$ which could induce the formation of Pythium zoospores and might be baited with the water samples. Pythium species might also be washed out into the fish pond from the plant root and were collected during sampling.

The sampling for tracing oomycetes was carried out in summer when water temperature was high $\left(25-30{ }^{\circ} \mathrm{C}\right)$ which enable fish to fight infection much better (Bly et al., 1994). Fish are not known to be infected during high temperature as the oomycetes produce oospores (Beakes and Bartinicki-Garcia, 1989) for survival during the harsh environment. Oospores are highly resistant to heat, drying, and disinfectants (Klinger and Francis- Floyd, 1996). Favourable conditions like low water temperature (van West, 2006), low circulated water, low dissolved oxygen, high ammonia content (Klinger and Francis-Floyd, 1996) are responsible for germination of the spore and produce zoospore which is mainly responsible for infection in fish. Moreover, oomycetes infection can take place in fish when the physiological condition becomes minimal and rush handling (Bruno and Wood, 1999) of fish occur. However, high water temperature increases the physiological activity of fish.

Apart from environmental conditions, the baiting method used in this particular research was also very important. The bait, rice grain, used in this research is a plant origin that could have favoured plant pathogenic oomycetes. However, due to natural rarity or a failure to provide suitable conditions for oomycetes capture, certain species of oomycetes may not found frequently using baiting (Johnson et al., 2002).

The fish farm, used to study the diversity of oomycetes, is a very well managed aquaculture farm. They monitor the cultured and brood fish regularly for growth and to observe if there is any infection. Water supply process of the farm is also properly operated. They completely dry out their pond and clean the bottom mud after every culture interval and if any infection ensued. Moreover, they use antibiotics with the supplemented feed to prevent different bacterial diseases. Thus it is possible that fish pathogenic oomycetes may not be found from such a properly handled fish farm. 
During the sampling period, all of the collected water, fish mucus and apparently infected fish muscle samples were preserved at $4^{\circ} \mathrm{C}$ to favour the growth of oomycetes than bacteria (Lechmere, 1910). Fish pathogenic oomycetes can grow better at $18-22^{\circ} \mathrm{C}$ and can even grow at $4^{\circ} \mathrm{C}$, however, growth of bacteria become slower at such lower temperature. All of the samples contained a huge amount of bacteria which could result in loss of oomycetes. Thus to initiate the mycelium growth faster than bacteria it was necessary to provide such an environment.

Isolate 1 and 4 could not be identified as the sequence data had some background peaks in the chromatogram that GenBank could not trace the closest homology. These background noises are either the result of contamination during the study period or problem of the sequencing company as a result of low template concentration. ITS sequences of some Pythium species had not enough nucleotides to compare the species ideally with GenBank databases, for example, isolate 7 (identified as Pythium sp.) and 9 (Pythium sp.) had only $680 \mathrm{bp}$ and $660 \mathrm{bp}$ search sequence length. The constructed phylogeny tree also show that the alias of isolate 7 and 9 , respectively $7 \mathrm{~F}$ and $9 \mathrm{~F}$, produce some differences. Moreover, these differences can also arise due to sequencing error or overlapping of nucleotides. After investigating the phylogeny tree an alignment of isolate 2 (identified as Pythium catenulatum), 3 (Pythium sp.), 5 (Pythium sp.), 8 (Pythium rhizo-oryzae) and 9 (Pythium sp.) were generated to check whether these species are identical or not. The alignment data completely agreed with the hypothesis; however, four nucleotides of those species were not identical which could be the result of short search sequence length of isolate 9. The above hypothesis indicates that these isolates are different strains of a particular Pythium species based on ITS sequence.

All of the 11 isolates of Pythium spp. were compared with the recorded species based on ITS sequencing of GenBank databases. One of the major limitations of the databases is that there is a lack of biodiversity studies on the oomycetes. To confound this there are a number of incorrectly identified DNA sequences in the available public databases. Inevitably, this situation will result in incorrect identification of species (Bridge et al., 2003) and makes it difficult to understand the true extent of all possible oomycetes species that are pathogenic to fish (Hulvey et al., 2007). The result suggests that fish pathogenic oomycetes such as Saprolegnia, Aphanomyces may be absent in well managed fish farms in summer, however, this concept is still unclear. Larger research and intense sampling could provide a holistic picture of the whereabouts of the fish pathogenic oomycetes in summer.

\section{Conclusions}

The research work was partially successful in determining the diversity of oomycete species present in the fish ponds of Reliance Aqua Farm located in Mymensingh in summer. Eleven isolates were separated from the water samples and were sent off for sequencing to 1st Base in Malaysia. No oomycete species was present in the mucus samples of tilapia and apparently infected muscles of koi and shing. Analogy of the separated isolates with the existing data in GenBank based on ITS sequences revealed that nine of the isolates were Pythium spp.; Phylogeny tree analyses reveal that six of the isolates are placed within clade B1 and other three of the isolates are of clade B2. The results of the present study partially suggest that plant pathogenic oomycetes of Pythium genera were found in the fish farm during the summer in Mymensingh, Bangladesh. This identification process is recommended to be continued for the same farm as worldwide the prevalence of fish pathogenic oomycetes increases in winter. Moreover, a clear concept on fish pathogenic and also non-pathogenic oomycetes can be acquired through intensive sampling for oomycetes in a broad circumstance in future. None the less, this piece of research work lays a platform for future research in the field of oomycete studies in Bangladesh.

\section{Acknowledgements}

Authors would like to acknowledge the owner, Hritesh Pondit, of the Reliance Aqua Farm who was very interested about this research and gave me the opportunity to collect samples from his fish farm. The authors greatly acknowledge the financial support of the IFS (A/5788-1) and COMSTECH as well as the Ministry of Science and Technology (BS-44, 2014-2015). The authors would also like to acknowledge the contribution of the Head of the departments, Department of Biotechnology, Department of Fisheries Biology and Genetics, and Central Laboratory, Bangladesh Agricultural University, BAU for providing equipment and technical supports during the research.

\section{Conflict of interest}

None to declare. 


\section{References}

Afzali SF, MD Hassan, I Sharifpour, M Afsharnasab and S Shankar S, 2015. Experimental Infection of Aphanomyces invadans and susceptibility in seven species of Tropical fish. Vet. World, 8: 1038-1044.

Alcala AVC, 2013. Management of damping-off caused by Pythium spp. in organic vegetable production in the Pacific Northwest. PhD Thesis, Department of Plant Pathology, Washington State University, Washington, USA. pp. 1-282.

Androusse AE, AE Aissami, M Rahouti, H Lahlou, SB Abdellah and FS Murandi, 2007. First record of three species of Pythium from Moroccan waters. Acta Bot. Malacit., 32:35-40.

Bala K, N Gautam and B Paul, 2006. Pythium rhizo-oryzae sp. nov.isolated from paddy fields: taxonomy, ITS region of rDNA, and comparison with related species. Curr. Microbiol., 52: 102-107.

Beakes GW and SBartinicki-Garcia, 1989. Ultrastructure of mature oogonium-oospore wall complexes in Phytophthora megasperma: a comparison of in vivo and in vitro dissolution of the oospore wall. Mycol. Res., 93: 321-334.

Beakes GW, SL Glockling and S Sekimoto, 2012. The evolutionary phylogeny of the oomycete "fungi". Protoplasma, 249: 3-19.

Bly JE, LA Lawson, E Abdel-Aziz and LW Clem, 1994. Channel catfish, Ictalurus punctatus, immunity to Saprolegnia sp. J. Appl. Aquacult., 3: 35-50.

Bondad-Reantaso MG, SC Lumanlan, JM Natividad and MJ Phillips, 1992. Environmental monitoring of the epizootic ulcerative syndrome (EUS) in fish from Munoz, Nueva Ecija in the Philippines. In Diseases in Asian Aquaculture 1, Eds., Shariff, M., RP. Subasinghe and JR. Arthur. Manila, Asian Fisheries Society, pp. 490.

Bridge PD, PJ Roberts, BM Spooner and G Panchal, 2003. On the unreliability of published DNA sequences. New Phytol., 160: 43-48.

Bruno DW and BP Wood, 1999. Saprolegnia and other Oomycetes. In Fish Diseases and Disorders, Vol. 3, Viral, Bacterial and Fungal Infections, Eds., Woo, PTK. and DW. Bruno. CABI Publishing, Wallingford, Owon, United Kingdom, pp. 599-659.

Czeczuga B, 1996. Species of Pythium isolated from eggs of fresh-water fishes. Acta Mycol., 31: 151-161.

Czeczuga B, B Kiziewicz and Z Danilkiewicz, 2002a. Zoosporic fungi growing on the specimens of certain fish species recently introduced to Polish waters. ActaIchtyol. Pisc., 32: 117-125.

Czeczuga B, B Kiziewicz and A Godlewska, 2004. Zoosporic fungi growing on eggs of Coregonus lavaretusholsatus Thienemann, 1916 from Lake Wdzydzein Kaszuby. Pol. J. Environ. Stud., 13: 355-359.

Czeczuga B, M Kolowska and A Godlewska, 2002b. Zoosporic aquatic fungi growing on dead specimens of 29 freshwater crustacean species. Limnologica, 32: 180-193.

Czeczuga B and E Muszyfska, 1996. Growth of zoosporic fungi on the eggs of North Pacific salmon of the genus Oncorhynchus in laboratory conditions. ActaIchtyol. Pisc., 26: 25-37.

Dick MW, 2001.Straminipilous fungi: systematics of the Peronosporomycetes including accounts of the marine straminipilousprotist, the plasmodiophorids and similar organisms, Kluwer Academic Publishers, London, UK.

Diéguez-Uribeondo J, J Cerenius and K Söderhäll, 1996. Physiological characterization of Saprolegnia parasitica isolates from brown trout. Aquaculture, 140: 247-257.

Diéguez-Uribeondo J, JM Fregeneda-Grandes, L Cerenius, E Pérez-Iniesta, JM Aller-Gancedo and MT Tellería, 2007. Re-evaluation of the enigmatic species complex Saprolegniadiclina-Saprolegniaparasitica based on morphological, physiological and molecular data. Fungal Genet. Biol., 44: 585-601.

El Aziz MAA, GM Kameland MA Mahmoud, 2004. Seasonal study, histopathological and treatment trial on Saprolegniosis in some fish farms. Proceedings of 1st Scientific conference of the Faculty of Veterinary Medicine, 1-4 September 2004, Moshtohor, Cairo University, Cairo. Edited by: Faculty of Veterinary Medicine, pp. 1-16.

FAO, 2015. Global Aquaculture Production database updated to 2013 - Summary information. Available: http://www.fao.org/3/a-i4899e.pdf.

Fernandez-Beneitez MJ, ME Ortiz-Santaliestra, M Lizana and J Dieguez- Uribeondo, 2007. Saprolegnia diclina: another species responsible for the emergent disease 'Saprolegnia infections' in amphibians. FEMS Microbiol. Lett., 279: 23-29.

Fry WE and NJ Grünwald, 2010. Introduction to Oomycetes. Available: DOI:10.1094/PHI-I-2010-1207-01.

Fry WE, NJ Grünwald, DEL Cooke, A McLeod, GA Forbes and K Cao, 2009. Population genetics and population diversity of Phytophthora infestans. In Oomycete Genetics and Genomics: Diversity, Interactions and Research Tool, Eds., Lamour, K. and S. Kamoun. Wiley-Blackwell, Hoboken, NJ, pp. 139-164. 
Grünwald NJ, EM Grossand CM Press, 2008. Phytophthora ramorum: a pathogen with a remarkably wide host range causing sudden oak death on oaks and ramorum blight on woody ornamentals. Mol. Plant Pathol., 9: 729-740.

Hardham AR, 2005. Phytophthora cinnamomi. Mol. Plant Pathol., 6: 589-604.

Hulvey JP, DE Padgett and JC Bailey, 2007. Species boundaries within Saprolegnia (Saprolegniales, Oomycota) based on morphological and DNA sequence data. Mycol. Res., 99: 421-429.

Johnson TW, RL Seymour and DE Padgett, 2002. Biology and systematics of the Saprolegniaceae. Available:http://dl.uncw.edu/digilib/biology/fungi/taxonomy\%20and\%20systematics/padgett\%20book

Judelson HS 2009: Sexual reproduction in oomycetes: biology, diversity, and contributions to fitness. In: K Lamour and S Kamoun (Editors), Oomycetes genetics and genomics: diversity, interactions, and research tools. John Wiley \& Sons, Inc., Hoboken, New Jersey, Canada. pp. 121-138.

Kamoun S, 2009. Plant Pathogens: Oomycetes (water mold). In Encyclopedia of Microbiology (Third Edition), M, Schaechter. Academic Press, Waltham, USA. pp. 689-695.

Kaufmann MJ and JW Gerdemann, 1958. Root and stem rot of soybean caused by Phytophthora sojae n. sp. Phytopathology, 48: 201-208.

Khan MH, L Marshall L, RE Thompson, RE Campbell and JH Lilley, 1998. Susceptibility of five species (Nile tilapia, rosy barb, rainbow trout, stickleback and roach) to intramuscular injection with the oomycete fish pathogen, Aphanomyces invadan. Bull. Eur. Assoc. Fish Pathol., 18: 192-197.

Klinger RE and R Francis-Floyd, 1996. Fungal Diseases of Fish. Institute of Food and Agricultural Sciences, University of Florida. Available: http://www.simply discus.com/library/disease_medications/external /fungaldiseases.html

Lechmere AE, 1910. An Investigation of a Species of Saprolegnia. New Phytol., 9: 305-319.

Lee SB and Taylor JW, 1992. Phylogeny of five fungus-like protoctistan Phytophtora species, inferred from the Internal Transcribed Spacers of ribosomal DNA. Mol. Biol. Evol.9: 636-653.

Levesque CA and MD Cock, 2004. Molecular phylogeny and taxonomy of the genus Pythium. Mycol. Res., 108: $1363-1383$.

Lilley JH, RB Callinan, S Chinabut, S Kanchanakhan, IH Macrae and MJ Phillips, 1998. Epizootic ulcerative syndrome (EUS) technical handbook, Aquatic Animal Health Research Institute, Bangkok, Thailand.

Matthewes VD, 1931. Studies on the genus Pythium.Chapel Hill, The University of North Carolina press, 1931, pp. 136.

Noga EJ, 1993. Water mold infections of freshwater fish: Recent advances. Annu. Rev. Fish Dis., 3: 291-304.

Peay KG, Kennedy PG and Bruns TD, 2008. Fungal Community Ecology: A Hybrid Beast with a Molecular Master. BioSci., 58:799-810.

Petrisko JE, CA Pearl, DS Pilliod, PP Sheridan, CF Williams, CR Peterson and RB Bury, 2008. Saprolegniaceae identified on amphibian eggs throughout the Pacific Northwest, USA, by internal transcribed spacer sequences and phylogenetic analysis. Mycologia, 100: 171-180.

Phillips AJ, VL Anderson, EJ Robertson, CJ Secombes and P Van West 2008. New insights into animal pathogenic oomycetes. Trends Microbiol., 16: 1-40.

Plaats-Niterink AJVD, 1981. Monograph of the genus Pythium: Studies in Mycology 21, Centraal-bureau voor Schimmel cultures, Baarn, Netherland.

Robideau GP, AWAMD Cock, MD Coffey, H Voglmayr, H Brouwer, K Bala, DW Chitty, ND Saulniers, QA Eggertson, CMM Gachon, CH Hu, FCK Pper, TL Rintoul, E Sarhan, ECP Verstappen, Y Zhang, PJM Bonants, JB Ristaino and CA Levesque, 2011. DNA barcoding of oomycetes with cytochrome c oxidase subunit I and internal transcribed spacer. Mol. Ecol. Resour., 11: 1002-1011.

Roudsary MK, SM Okhovat, M Mirabolfathi and M Kafi, 2010. First record of Pythium catenulatum and Pythium okanoganense on turf grasses in Iran. Plant Prot., 2: 325 - 328.

Sarowar MN, AH van den Berg, D Mclaggan, MR Young and P van West, 2013. Saprolegnia strains isolated from river insects and amphipods are broad spectrum pathogens. Fungal Biol., 117: 752-763.

Sathi SC and RD Khulbe, 1983. Pythium gracile, as parasite on fish gills. Indian Phytopathol., 36: 587-588.

Thompson KD, JH Lilley, SC Chen, A Adams and RH Richards, 1999. The immune response of rainbow trout (Oncorhynchus mykiss) against Aphanomyces invadans. Fish Shellfish Immunol., 9: 195-201.

Van West P, 2006. Saprolegnia parasitica, an oomycete pathogen with a fishy appetite: new challenges for an old problem. Mycologist 20: 99-104.

Xiao LKE, JG Wang, ZM Gu and XN Gong, 2009. Morphological and molecular phylogenetic analysis of two Saprolegnia sp. (Oomycetes) isolated from silver crucian carp and zebra fish. Mycol. Res.,113: 637-644. 